\title{
Maternal Fever
}

National Cancer Institute

\section{Source}

National Cancer Institute. Maternal Fever. NCI Thesaurus. Code C92828.

The elevation of body temperature in a pregnant mother above 38 degrees $\mathrm{C}$ or more than 101 degrees F, and may be indicative of an infection. 